\title{
Now That You Have It, What Are You Going To Do With It and How?
}

\section{Citation}

Britton, Anne. 2000. Now that You Have It, What are You Going to Do With It and How. Art Documentation: Journal of the Art Libraries of North America 19 (2): 41-43

\section{Permanent link}

http://nrs.harvard.edu/urn-3:HUL.InstRepos:39060039

\section{Terms of Use}

This article was downloaded from Harvard University's DASH repository, WARNING: No applicable access license found.

\section{Share Your Story}

The Harvard community has made this article openly available. Please share how this access benefits you. Submit a story. 


\title{
REAL O R N O T
}

\section{Now That You Have It, What Are You Going To Do With It and How?}

\author{
by Anne Britton
}

Cataloging Internet art creates an opportunity for libraries to provide immediate access to contemporary artworks for an unlimited number of patrons. In short, Internet art integrated in a library catalog can distribute art, cheap and fast, to a wider audience than artists' books ever could. In this paper I will discuss some practical aspects of cataloging and archiving Internet art. My discussion is divided into five sections: Definitions, Selection, Acquisition, Cataloging, and Preservation.

\section{Definitions}

There are many similarities between artists' books and Internet art. Like an artist's book, Internet art can be linear, nonlinear, self-published, gallery-driven, high production, low production, technically complex, technically simple, ephemeral, archival, purely pictorial, all-text, interactive, prosaic, poetic, goofy, gimmicky, one-liner-ish, accessible, inaccessible, art, documentation and surrogate.

One example of an artists'-book-Internet cross-over artist is Claude Closky, who has made books like First Thousand Numbers Classified in Alphabetical Order (1989) and 100 Photographs Which are Not Photographs of Horses (1995). Critic Lynne Cooke of Dia writes about Closky's cross-over to Internet art: "Whether in the form of cheaply printed books, unlimited editions of singlechannel videos, posters or wallpaper, multiples are Closky's preferred vehicles. Given its demotic range, ready availability, and relatively low-cost production, the World Wide Web has become for this young French artist an equally appealing medium in which to work." 1

There are a few articles which articulate the connection between traditional contemporary artists' books on the one hand and Internet art on the other. In particular, see The Structure of the Virtual Book by Chris Peregoy, ${ }^{2}$ Is it a Book? by Karen Drayne, Barbara Davison, and Emily-Jane Dawson, ${ }^{3}$ and The Self-Conscious Codex: Artists' Books and Electronic Media by Johanna Drucker. ${ }^{4}$ There are many books and articles on Internet art generally, including the recent Digital Dialectic edited by Peter Lunenfeld. ${ }^{5}$

\section{Selection of "Virtual Artist Books"}

There are several new and established cultural efforts focused on Internet art and its display, meaning, techniques, dissemination and so on. The Web sites of these efforts are generally important sources for compilations of links. They include the Musée d'Art Contemporain de Montréal; Walker Art Center;
Nettime discussion list; 7-11 discussion list; the New York Times (Matthew Mirapaul's arts@large column); Zentrum für Kunst und Medientechnologie; adaWeb; the commercial Wired Digital Inc; the Museum of Web Art; and many others.

When you are out there surfing, you may notice that compilations of links to Internet art, that is, art made from Internet tools, are variously named. Uncontrolled categorical headings include: "Artist's Projects" (Artsource), "New Media" (Artsource), "Artist studios/Digital artists" (Art on the Net), "Artist studios/Hacker artists" (Art on the Net), "Projects" (NYU's Interactive Telecommunications Program), "Art Sites" (Museum of Web Art), "Networks" (7th Annual NY Digital Salon), "Online Projects" (Oxford University's Laboratory), "Works online" (OW@C), as distinct from "Artists' Sites" (OW@C). More about vocabulary later. Selection aids like reviews are commonly found online (try Leonardo Almanac), also offline in Art Monthly (Michael Gibbs), and Artforum.

\section{Acquisition}

Having selected some Internet resources, the information professional then considers access. Roy Tennant writes in the January 2000 issue of American Libraries, "When one decides that a resource is worth collecting, how does one 'collect' it? Is pointing to it from a Web page sufficient? Should the resource be cataloged in the library catalog? What is a collection? Is it what you own, or everything you can encompass with links as well as walls?"6

A collection of Internet art can consist of either locally held or remote resources, or both. A lot of Internet art lacks the stability on which much of art history so far has been predicated and which is so helpful to librarians in acquiring and cataloging a particular published resource. As Steve Holtzman notes: "Even if a basic property of digital technology is perfect repeatability, 'repeatable' is exactly what nonlinear hypermedia is [not]."7

One might encompass this flux by acquiring/archiving an actual copy to hold in your local collection. The Sales Department of MT Enterprises' "Visual-Text Art Venue (VTAV)," (mteww.com/VTAV/sales.html), a parody site, offers work for sale in four formats: "1. Artifact; 2. license; 3. shared copyright; 4. full copyright." An "artifact" is "a hard-copy print" (signed by the artist); a "license" is the work "on a floppy disk" and "allows one to create as many copies as one wishes of the work for personal use." With "Shared copyright" "the collector 
shares [with the artist] all rights regarding publication" and "Full copyright" gives the collector "all rights to...publication."

On the other hand, there are remote resources. As Eugenie Prime, Hewlett-Packard's Library Manager, says: "Own nothing. Maintain nothing. Access everything. That's my mantra." 8 Put another way, remote resources require less tech support overall. In a Web-based library catalog, the beauty of cataloging the link (using, for example, MARC's 856 field) as opposed to archiving and cataloging the object itself, is that little or no tech support is required. ${ }^{9}$

Further, many works of Internet art are already archived and fully accessible. Turbulence, for one, has very functional archived copies of some thirty-four works from 1996 to the present. Rhizome, also, with a database of some seventy works, provides access to both the original URL and often its "clone." Also, as you would expect, cataloging is unfortunately often non-standardized and varies in fullness from archive to archive (at least for now). In contrast to archives are collections of links. A functionality check I conducted earlier this year of links compiled (but not archived) by the Musée d'Art Contemporain Montréal showed, of 255 total "Web Art Projects," (that is, artworks) seventy-six per cent active links and twenty-four per cent inactive ones during random sampling in January and February 2000. Of the seventyeight total "Sites Presenting Web Art Projects," eighty-four per cent were active, sixteen per cent inactive.

\section{Cataloging}

In the cataloging process, one solution to the problem of shiftiness is to note that a particular site has been cataloged on a particular day. That is, the catalog record might include a note such as: "(Viewed via the World Wide Web on March 20, 2000)."

In cataloging either remote or local resources at the level of data fields, one might choose MARC, Dublin Core, or VRA's core data fields, for instance. Other data fields are worth considering as well, like those for interactive telecommunications projects at New York University (http:/ /itp.nyu.edu/itpWeb/ $\mathrm{html} /$ prj_index.stm), which include fields for: "Type, Technology, Freshness Date, Plugin, Semester." Rhizome (http://www.rhizome.org/artbase/ab_indexing_info.html) also uses locally contrived data fields, some nominally identical to NYU: "Type, Technology, Category, Keyword." These fields are standard only at the local level, although some can be cleanly mapped to MARC or Dublin Core.

At the level of data values, catalogers need controlled vocabularies. Some archives of Internet art have created their own field-specific vocabularies. Rhizome, for instance, allows the following values in its "Technology" data field: "HTML, DHTML, QuickTime, CuSeeMe, Java, Perl, Flash, Shockwave, Javascript, VRML, RealPlayer, MP3, download, and E-mail." Rhizome's "Keyword" field is also controlled by a short word list which includes terms like: "Artificial Life, Broadcast, CDROM, Colonialism, Design, Labor, Language, Publish, Resistance, Responsibility, and Rumor."

At the risk of belaboring the point, let me mention one last word list. NYU's Interactive Telecommunications "Types" data field includes terms relevant to "virtual artists' books" as well as to more general, art-related Internet resources, such as: "Digital spaces, Games, Narrative space, Narratives, Portfolio, Web zines, Web exhibit/Resource, Webcasting, Data visualization, Tutorial."

One last comment about cataloging. If at all possible, I think that catalog records for Internet art should include a summary of the work (e.g. MARC 520). ${ }^{10}$ One of the problems discovered in recent studies of user behavior with art-related electronic resources is a general lack of time on the part of the user. This would mean that instead of waiting for a work of art to finally download, the user might just give up. The text summary could also prove valuable if a link dies. The catalog record would remain as documentation of the site's existence, just as photodocumentation gives a history to performance art of the 1960s and 1970s.

\section{Preservation}

During a recent panel discussion on computers and art, Shaun Lovejoy voiced his exasperation at the use of the term "virtual" to mean that information lacks corporeality. He said of computer data: "It's real! It's matter!"11 Obviously, computer files exist and can cease to exist if not properly stored.

Rick Rinehart of the Berkeley Art Museum and the Conceptual and Intermedia Art Online (CIAO) project believes that it is "critical to preserve both the look and feel (or behavior) and the content" of an Internet artwork.12 For Internet artworks archived in the CIAO database, Rinehart looks to three preservation methods: 1) Static preservation (that is, all hardware, software, plugins, etc., which is expensive); 2) Migration of data (which preserves content but not behavior); and 3) Emulation, a strategy proposed by Jeff Rothenberg of RAND in which the object is encoded or "wrapped" in a shell of electronic data, and the shell, not the object, is migrated over time. Rothenberg's idea has not yet been written into software.

To summarize: The time-consuming process of selecting Internet art is expedited by selection aids found both online and offline, and particularly by compilations of links. These compilations often have confusing titles, but persistence pays off. Acquiring copies of Internet art requires upkeep of hardware, software, and peripherals, while "acquiring" a remote resource suggests acceptance of Internet art as an ephemeral medium. Copyright concerns are central to both types of acquisition. General guidance for cataloging Internet art can be found in the standard literature for cataloging electronic resources. As with artists' books, standard cataloging guidelines are broadly helpful, especially in pointing to the value of bibliographic documentation beyond the item in hand. Vocabularies for Internet art are emerging, but several existing archives use locally controlled vocabularies. And last, but not least, practices for archiving digital objects are still being developed. Stay tuned.

One last comment: I would argue that funding for the abovementioned library work relating to integrated access might be justified in several ways. 1) Art audiences can interact with art objects on their own time, outside of the white cube of the gallery or museum. 2) The library can serve as a long-term venue for digital art. 3) If an Internet artwork is truly ephemeral (by design or accident), the catalog record will provide documentation, if nothing else. Finally, 4) currently available collections of works and links are incomprehensive, variously standardized, and existing outside of shared bibliographic utilities. 


\section{Notes}

1. diacenter.org/closky/intro.html

2. <imda.umbc.edu/people/chris/chrispaper.html>. (1995). Viewed 3/1/00.

3. <www.philobiblon.com/isitabook> (1997). Viewed 3/1/00.

4. Substance 82, 26, no. 1 (Spring 1997). Viewed 3/1/00.

5. Cambridge, MA: MTT Press, 1999.

6. “Determining our Digital Destiny," American Libraries 31, no.1 (January 2000): 56.

7. Steve Holtzman, Digital mosaics: the aesthetics of cyberspace. New York, NY: Simon and Schuster, 1997: 189

8. Online 23, no.5 (September/October 1999): 30.

9. Lena Stebley, "Faculty Perspective on Teaching with Digital Images; Results of Focus Groups with Art Faculty," Visual Resources 14, no. 4. (1999): 472.

10. Stebley, op.cit., 473.

11. "Negotiating the Tensions Between Two Divergent Worlds: Art and Science," panel, College Art Association annual conference, New York, NY, 2/24/00.

12. Archiving the Nonarchival, Part 2," panel, College Art Association annual conference, New York, NY, 2/26/00.

\section{Internet Art Resources: Select Examples}

by Doro Boehme and Anne Britton

http://www.geocites.com/rushca26/resources.html

\section{COMPILATION OF ARTWORKS:}

adaWeb:http://adaWeb.walkerart.org

@art: http://www.art.uiuc.edu/Aart/main.html

The Thing:

http:/ / www.thing.net/

http://old.thing.net

\section{INDIVIDUAL ARTWORKS:}

1am: http://www.1am.org

Blast: http://www.blast.org/menu.html

Freud-Lissitzky Navigator: http://visarts.ucsd.edu/ manovich/FLN

Kac: http://www.ekac.org/multimedia.html

\section{HISTORY, THEORY, CRITICISM:}

Artswire: http://www.artswire.org

Ctheory: http://www.ctheory.com/ctheory.html

Rhizome discussion list: http://www.rhizome.org/subscribe/

\section{ACQUISITION:}

Visual Resources Association Copyright page:

http://www.oberlin.edu/ art/vra/copyright.html

\section{CATALOGING:}

MARC:

http://lcWeb.loc.gov/marc/bibliographic/ecbdhome.html

\section{EXAMPLES OF CATALOGED ARTWORKS:}

Museum of Modern Art Library: (search:+http+"artists Web pages"): http:/ /library.moma.org

\section{PRESERVATION:}

Preserving Access to Digital Information (PADI), National Library of Australia: http://www.nla.gov.au/padi/topics/1.html

\section{EXAMPLE OF AN ARCHIVE:}

Turbulence: http://www.turbulence.org 